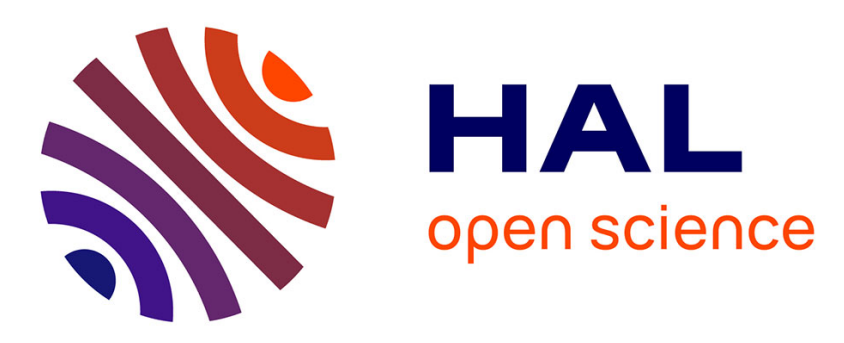

\title{
In situ hybridization of a radioactive RNA probe on resin-embedded legume root-nodule sections: a tool for observing gene expression in the rhizosphere?
}

Olivier Schumpp, Hassen Gherbi, Jacques Escoute, Hélène Payre, Jean-Jacques Drevon

\section{To cite this version:}

Olivier Schumpp, Hassen Gherbi, Jacques Escoute, Hélène Payre, Jean-Jacques Drevon. In situ hybridization of a radioactive RNA probe on resin-embedded legume root-nodule sections: a tool for observing gene expression in the rhizosphere?. Agronomie, 2003, 23 (5-6), pp.489-493. 10.1051/agro:2003023 . hal-00886201

\section{HAL Id: hal-00886201 https://hal.science/hal-00886201}

Submitted on 1 Jan 2003

HAL is a multi-disciplinary open access archive for the deposit and dissemination of scientific research documents, whether they are published or not. The documents may come from teaching and research institutions in France or abroad, or from public or private research centers.
L'archive ouverte pluridisciplinaire HAL, est destinée au dépôt et à la diffusion de documents scientifiques de niveau recherche, publiés ou non, émanant des établissements d'enseignement et de recherche français ou étrangers, des laboratoires publics ou privés. 


\title{
In situ hybridization of a radioactive RNA probe on resin-embedded legume root-nodule sections: a tool for observing gene expression in the rhizosphere?
}

\author{
Olivier SCHUMPPa ${ }^{\mathrm{a}}$, Hassen GHERBI ${ }^{\mathrm{a}}$, Jacques ESCOUTE ${ }^{\mathrm{b}}$, Hélène PAYRE ${ }^{\mathrm{a}}$, Jean-Jacques DREVON ${ }^{\mathrm{a}}$ \\ ${ }^{a}$ UMR Rhizosphère et Symbiose, INRA, place Pierre Viala, 34060 Montpellier Cedex 1, France \\ ${ }^{\mathrm{b}}$ CIRAD/BIOTROP UMR BDPPC, avenue d'Agropolis, 34060 Montpellier Cedex, France
}

(Received 14 October 2002; accepted 13 March 2003)

\begin{abstract}
In this work we performed in situ hybridization of a carbonic anhydrase RNA ${ }^{35}$ S-labeled probe on nodule sections previously embedded in a methacrylate resin. The results were more precise and reproducible than those obtained on paraffin-embedded nodules. Thanks to the small thickness of the sections and the good preservation of tissue during sectioning, the specific localization of the carbonic anhydrase gene expression in the inner cortex of the nodule could be described quite precisely. It is argued that these results are consistent with the hypothesis of osmoregulation of the symbiotic nitrogen fixation. Moreover, the quality of these results with a radioactive probe makes it possible to consider using ISH for such rhizospheric applications as localizing and quantifying a microbial invasion of the endorhizosphere or the rhizoplan by using bacterial- or fungal-specific RNA probes, and counting the number of radioactive dots per cell. However, major artifacts observed with a digoxegin RNA cold probe makes it necessary to recommend the use of a radioactive RNA probe for these prospects.
\end{abstract}

common bean / microscopy / rhizobia / rhizosphere / symbiotic nitrogen fixation

Résumé - Hybridation in situ d'une sonde ARN radioactive sur des coupes de nodosités de légumineuses incluses dans une résine méthacrylique : un outil pour observer l'expression génique dans la rhizosphère ? Dans ce travail, nous avons réalisé une hybridation in situ d'une sonde ARN d'anhydrase carbonique marquée au ${ }^{35} \mathrm{~S}$, sur des coupes de nodosités préalablement incluses dans une résine méthacrylique. Grâce à la faible épaisseur des coupes et la bonne conservation des tissus durant la coupe, la localisation spécifique de l'expression du gène d'anhydrase carbonique dans le cortex interne des nodosités a pu être décrite très précisément. Il est argumenté que cette localisation est en accord avec l'hypothèse d'osmorégulation de la fixation symbiotique d'azote. De plus, la qualité de ces résultats avec une sonde radioactive suggère qu'il serait possible d'utiliser l'hybridation in situ pour des applications telles que la localisation et la quantification d'une invasion microbienne de l'endorhizosphère ou du rhizoplan en utilisant des sondes ARN spécifiques de champignons ou de bactéries, et en comptant le nombre de signaux radioactifs par cellule. Il est recommandé d'utiliser un marquage radioactif des sondes, en raison des artefacts observés dans ce travail avec une sonde ARN marquée à la digoxygénine.

fixation symbiotique d'azote / haricot / microscopie / rhizobia / rhizosphère

\section{INTRODUCTION}

The embedding of plant tissues for in situ hybridization is generally performed within paraffin. However, the inclusion in paraffin requires $2-3$ days at $60^{\circ} \mathrm{C}$, which alters the cellular structures and the antigenic sites of proteins [1]. Moreover, the cut has to be thick in order to avoid cell distortions [18]. By contrast, methacrylic resins allow inclusions at low temperatures with a better preservation of antigenic sites. In addition, their toughness allows cutting without distortions [1] for a better analysis of morphological differences between cells, as previously shown with soybean nodules [20]. Since such resins can be deresined, they may be quite interesting for in situ hybridization.

In our group we are researching genes whose overexpression in the cortical parenchyma of legume root-nodules may relate to the function of this tissue to osmoregulate the oxygenation of the nodule $[5,6]$. The nodular cortex, as illustrated in 


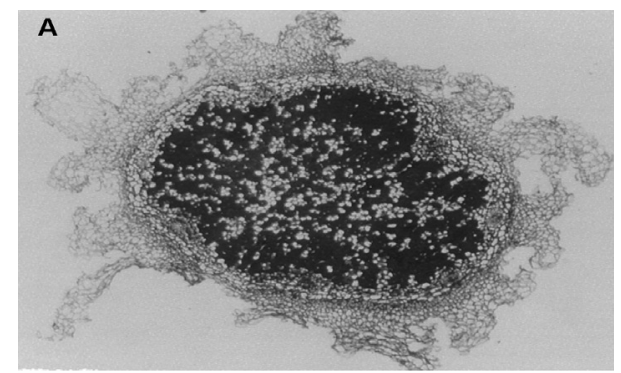

B

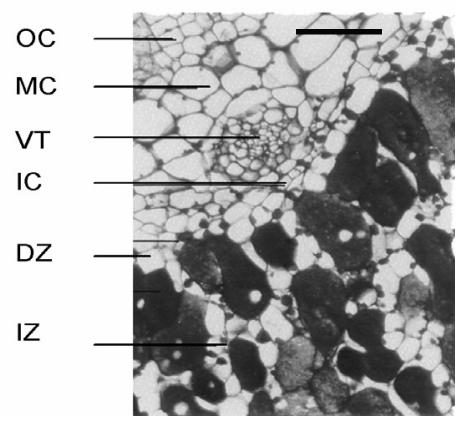

Figure 1. Nodule morphology. (A) transverse section stained with periodic acid-schiff and naphtol blue black; (B) cortex is subdivided into: outer cortex (OC), middle cortex (MC), i.e. the cell-layers localized between the vascular traces and the outer cortex [10], inner cortex (IC), i.e. the cell-layers located between the vascular traces and the most internal non-infected cells surrounding the infected zone [20], and the distributing zone (DZ), that separates the IC from the infected zone (IZ) where atmospheric $\mathrm{N}_{2}$ is fixed by bacteroids, the organite form of the symbiotic rhizobia [14]. The vascular traces (VT) are distributed in-between MC and IC. Dark bar corresponds to $50 \mu \mathrm{m}$.

Figure 1 for Phaseolus vulgaris, can be divided into external (EC), middle (MC), i.e. the cell-layers localized between the vascular traces and the outer cortex [10], and internal (IC), i.e. the cell-layers located between the vascular traces and the most internal non-infected cells surrounding the infected zone [20]. Vascular traces run in-between the IC and MC. A celllayer named the distributing zone (DZ) would separate the IC from the infected zone (IZ) where atmospheric $\mathrm{N}_{2}$ is fixed by bacteroids, the organel form of the symbiotic rhizobia [14]. A major function of the specialization of the legume root-nodule is to preserve a microaerobic environment for the assimilatory reduction of $\mathrm{N}_{2}$ into $\mathrm{NH}_{3}$ by nitrogenase. Indeed, this enzyme is inactivated by $\mathrm{O}_{2}$ traces, and its gene-transcription requires a partial $\mathrm{O}_{2}$ pressure lower than $0.2 \%$ [3]. Moreover, the ATP requirement for $\mathrm{N}_{2}$ reduction is so high that the concentration of $\mathrm{O}_{2}$ seems to be regulated at a sublimiting level for nitrogenase in the infected-cells $[7,9]$.

To test the technical reliability of in situ hybridization on resin-embedded nodules, we used a carbonic anhydrase (CA) gene that is specifically expressed in the nodule inner-cortex [4]. Based on reproducible results with ${ }^{35} \mathrm{~S}$ radiolabeling shown in this work, we discuss the potential of using similar methodology with bacterial- or fungal-specific RNA probes to localize and quantify a microbial invasion of the endorhizosphere or the rhizoplan.

\section{MATERIALS AND METHODS}

\subsection{Culture of plants and bacteria and preparation of nodule sections}

Seeds of common bean (Phaseolus vulgaris) line BAT477 were surface-sterilized and inoculated with Rhizobium tropici CIAT 899, then grown in a liquid and aerated nutrient solution [21]. Nodules of 3-4 mm diameter were harvested 5 weeks after inoculation, cut into 2 hemispheres in a transverse plan [18] and immediately transferred into the following fixative at room temperature: $0.9 \%(\mathrm{w} / \mathrm{v})$ paraformaldehyde with $100 \mathrm{mM}$ cyclohexylamine, $10 \mathrm{mM}$ EGTA (ethyleneglycolbis( $\beta$-aminoethyl ether)-N,N,N',N'-tetracetic acid), $10 \mathrm{mM}$ $\mathrm{MgCl}_{2}$ and $1 \mathrm{mM} \mathrm{DTT} \mathrm{(dithiotreitol)} \mathrm{in} 100 \mathrm{mM} \mathrm{1,4-piper-}$ azidinediethane sulfonicacid (Pipes) buffer, pH 7.5 [12]. Vacuum was applied during the $6 \mathrm{~h}$ of incubation, with several interruptions until the nodule halves were all sunk into the fixative. Thereafter, the nodule halves were washed 3 times for $15 \mathrm{~min}$ with $10 \mathrm{mM}$ EGTA, $10 \mathrm{mM} \mathrm{MgCl} 2,1 \mathrm{mM}$ DTT and $100 \mathrm{mM}$ glycine in $10 \mathrm{mM}$ Pipes buffer at $\mathrm{pH} 7.5$, and incubated overnight in the same buffer without glycine.

The embedding in resin was performed with the procedure of Baskin et al. [1] with the following modifications: nodule halves were passed through ethanol-methacrylate series, 3:1 $(\mathrm{v} / \mathrm{v})$ for $3 \times 30 \mathrm{~min}, 1: 1(\mathrm{v} / \mathrm{v})$ for $2 \times 1 \mathrm{~h}, 1: 3(\mathrm{v} / \mathrm{v})$ for $30 \mathrm{~min}$, then incubated for $2 \times 1 \mathrm{~h}$ in methacrylate, and overnight in methacrylate with added $0.5 \%(\mathrm{w} / \mathrm{v})$ benzoin ethyl ether (Flucka). $10 \mathrm{mM}$ DTT was added to all resin mixtures and they were previously bubbled for $15 \mathrm{~min}$ with gaseous nitrogen before each incubation to displace dissolved oxygen. Nodule halves in liquid resin were transferred into plastic moulds (Leica), and covered with agarose film (Melinex film, Agarscientific) and an excess of resin for polymerization at $4{ }^{\circ} \mathrm{C}$ at $30 \mathrm{~cm}$ above a UV source of $365 \mathrm{~nm}$ for $20 \mathrm{~h}$ to solidify the resin. The embedding in paraffin was performed at $60{ }^{\circ} \mathrm{C}$ in series of toluidin, toluidin:paraffin $(1: 1, \mathrm{v} / \mathrm{v})$ and paraffin.

Nodule sections of $7 \mu \mathrm{m}$ in paraffin and $4 \mu \mathrm{m}$ in resin were performed with a microtome. They were floated on a drop of water on slides previously treated with Vectabon (Vector), heated at $45{ }^{\circ} \mathrm{C}$ for $4 \mathrm{~h}$ and incubated twice for $10 \mathrm{~min}$ in acetone to remove the resin. Tissues were then rehydrated, treated with proteinase $\mathrm{K}$ and incubated in triethanolamine$\mathrm{HCl}(\mathrm{pH}$ 8) with $0.5 \%$ acetic anhydride according to Kronenberger et al. [11]. All solutions were made in RNAsefree glassware with DEPC-treated water.

\subsection{Preparation of RNA probe}

The cloning of a $P v C A$ cDNA fragment for subsequent probe synthesis was performed from total RNA prepared from a $P$. vulgaris root-nodule cortex with a RNeasy Plant Mini Kit (Qiagen, GMBH, Germany). This RNA was treated with RNAse-free DNAse (Promega, USA) in order to avoid genomic DNA contamination. Two $\mu \mathrm{g}$ of RNA were reverse transcribed with MMLV reverse transcriptase (Promega) in the presence of an oligo-d(T) primer and dNTPs in a final volume of $50 \mu \mathrm{l}$. Two CA primers, forward CTKYTSAGRGAGAAGRMKGA, and reverse CCACAGCTTGAATTCTCC, were designed from conserved regions of several 
CA coding sequences for amplifying a 700-bp fragment [13]. The PCR reaction was carried out in a total volume of $25 \mu \mathrm{l}$, including $20 \mu \mathrm{M}$ of each dNTPs, $200 \mu \mathrm{M}$ of each CA primer, 0.5 unit of Taq DNA polymerase (Promega) and $1 \times$ Taq Promega buffer. The thermocycling profile was 35 cycles at $94{ }^{\circ} \mathrm{C}$ for $1 \mathrm{~min}, 55^{\circ} \mathrm{C}$ for $1 \mathrm{~min} 30 \mathrm{~s}$ and $72{ }^{\circ} \mathrm{C}$ for $1 \mathrm{~min}$. A control reaction where RNA was treated as above but without reverse transcriptase gave no amplification. The amplified fragment was cloned into a pGEM-T vector (Promega). It was used for sequencing with the automatic sequencing system from Applied Biosystems 373A (Foster City, CA, USA) and for synthesizing the ${ }^{35} \mathrm{~S}$-labeled RNA probes. The sequence was given the accession No. PVU547634 standard. It shares 86 and $90 \%$ of identity with the Glycine max and Medicago sativa $\mathrm{CA}$, respectively. To generate the sense or antisense probes, the plasmid was linearized with ApaI or PstI and transcribed with RNA polymerase SP6 or T7, respectively. Radioactive labeling was performed as previously described [8].

\subsection{In situ hybridization}

The in situ hybridization (ISH) with a radioactive probe was carried out according to Cox et al. [2] with the following modifications: radioactive RNA probes were heated at $80^{\circ} \mathrm{C}$ for $5 \mathrm{~min}$ in tRNA $0.15 \mathrm{~g} \cdot \mathrm{l}^{-1}$, Poly A $0.5 \mathrm{~g} \cdot \mathrm{l}^{-1}$ and DTT $300 \mathrm{mM}$, quickly cooled on ice and the following were added: formamide $50 \%, \mathrm{NaCl} 300 \mathrm{mM}$, TE buffer $\mathrm{pH} 7.5$ (Tris- $\mathrm{HCl}$ $10 \mathrm{mM}$, EDTA $1 \mathrm{mM}$ ), Dextran sulfate $10 \%, 1 \times$ Denhardt's reagent (QuantumBioprobe) and DTT $60 \mathrm{mM}$. The mixture $\left(5 \mu \mathrm{l} \cdot \mathrm{cm}^{-2}, 4000 \mathrm{cpm} \cdot \mu^{-1}\right)$ was applied onto slides and covered with coverslips to hybridize overnight at $42{ }^{\circ} \mathrm{C}$ in a humid box containing Whatmann paper saturated with $2 \times \operatorname{SSC}(1 \times$ $\mathrm{SSC}=0.15 \mathrm{M} \mathrm{NaCl}$ and $0.015 \mathrm{M} \mathrm{Na}$-citrate, $\mathrm{pH} 7$ ), and protected from light. The coverslips were carefully removed and the slides were washed for $4 \times 10 \mathrm{~min}$ in $4 \times \mathrm{SSC}$ with $5 \mathrm{mM}$ DTT, then incubated for $5 \mathrm{~min}$ in RNase buffer (Tris- $\mathrm{HCl}$ $10 \mathrm{mM} \mathrm{pH} 7.5$, EDTA $1 \mathrm{mM}$ and $\mathrm{NaCl} 0.5 \mathrm{M}$ ). The slides were then treated for $30 \mathrm{~min}$ with RNase A $\left(50 \mu \mathrm{g} \cdot \mathrm{ml}^{-1}\right)$ at $37^{\circ} \mathrm{C}$, and washed for $4 \times 15 \mathrm{~min}$ with RNase buffer with $5 \mathrm{mM}$ DTT. They were incubated for $30 \mathrm{~min}$ in $2 \times \mathrm{SSC}$ with $5 \mathrm{mM}$ DTT, and for $1 \mathrm{~h}$ in $0.2 \times \mathrm{SSC}$ with $5 \mathrm{mM}$ DTT, both at room temperature. The slides were coated with autoradiographic emulsion (LM1, Amersham) diluted in water (2/1), processed as recommended by the Amersham Company and stored for 1 month at $4{ }^{\circ} \mathrm{C}$. Development was performed for 1 min with a D-19 developer (Kodak), and colored with $0.02 \%$ toluidine blue. Observations were made with a Leica microscope DMRXA. Numeric pictures from ISH with resin or paraffin embedding were computerized using Photoshop software (Adobe).

ISH with a cold probe was performed for $1 \mathrm{~h}$ in a Tris- $\mathrm{HCl}$ buffer at pH 7.4 containing the antibody anti-Dig coupled to an alcaline phosphatase (Boehringer) at 1/250 and a blocking agent at $1 \%$, and for $3 \mathrm{~h}$ in a similar renewed mixture. The DigRNA labeling mix was performed with a kit (Boehringer) including $10 \mathrm{mM}$ A/C/GTP and $3.5 \mathrm{mMDig-UTP}$. The slides were washed afterwards in the similar Tris- $\mathrm{HCl}$ buffer, and a buffer containing $100 \mathrm{mM} \mathrm{NaCl}, 50 \mathrm{mM} \mathrm{MgCl}_{2}$ and $100 \mathrm{mM}$ Tris- $\mathrm{HCl} \mathrm{pH} 9.5$ with added NBT-BCIP and $1 \mathrm{mM}$ levamisole, an inhibitor of endogenous alcaline phosphatases. The
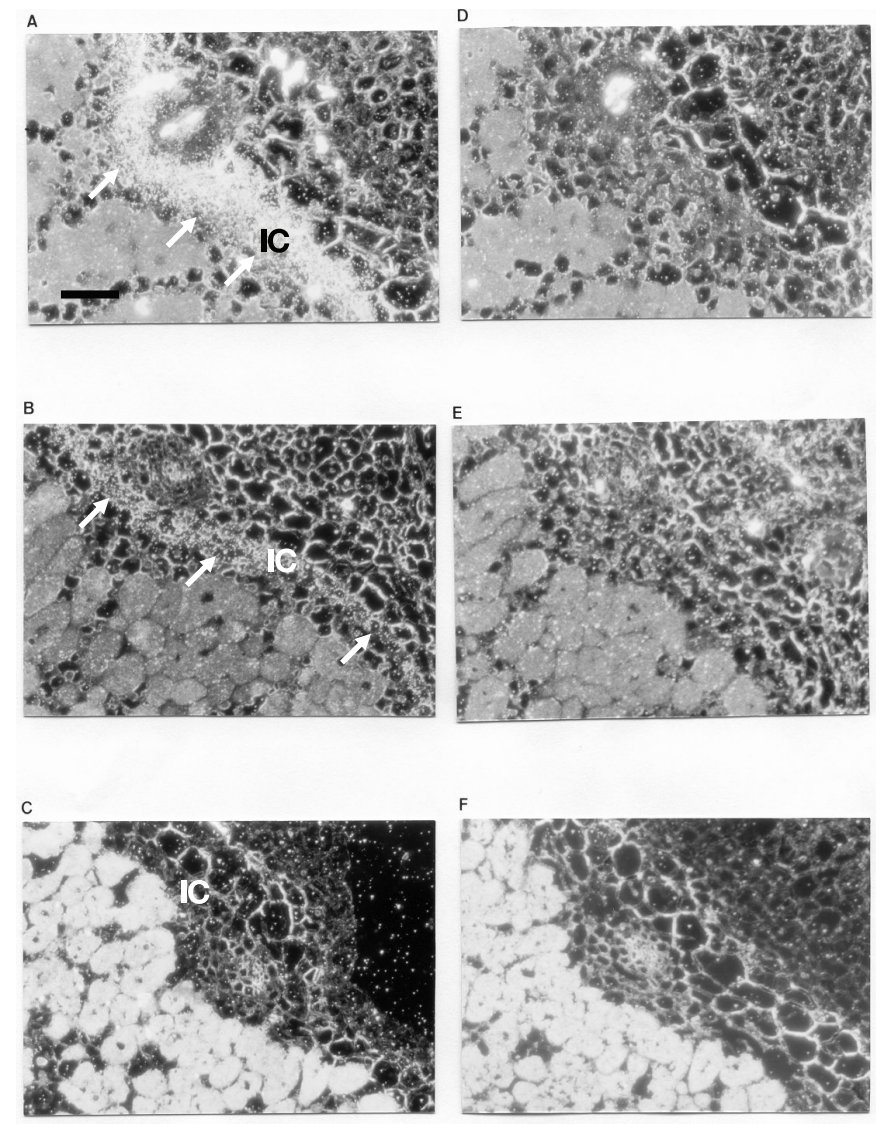

Figure 2. Variations in ISH signal with radioactive antisense (A, B and C) and sense- (D, E and F) $P v C A$ probes on 2 consecutive sections from 3 resin-embedded nodules. White arrows show ISH signals. Dark bar corresponds to $50 \mu \mathrm{m}$.

coloration was regularly checked. Generally a hybridization signal could be seen after 2-3 days.

\section{RESULTS}

\subsection{Hybridization with methacrylate embedding and a radioactive probe}

The radioactive signal observed in Figures 2A, $2 \mathrm{~B}$ and $2 \mathrm{C}$, shows that it is actually possible to obtain an ISH positive result with an antisense radioactive RNA probe on nodule sections that were initially embedded in a methacrylate resin. As shown in Figures 2D, 2E and 2F, there was no radioactive signal on consecutive sections treated with a similar ISH procedure but with the sense $P v C A$ probe. Since the latter could not hybridize with transcripts because it was homologous and not complementary to the CA mRNA, this result confirms that the radioactive signal observed in Figures 2A, $2 \mathrm{~B}$ and $2 \mathrm{C}$ was not artefactual.

The precision of the signal localization in methacrylateembedded nodules made it possible to investigate the topographic distribution of the $P v C A$ transcripts within nodule 


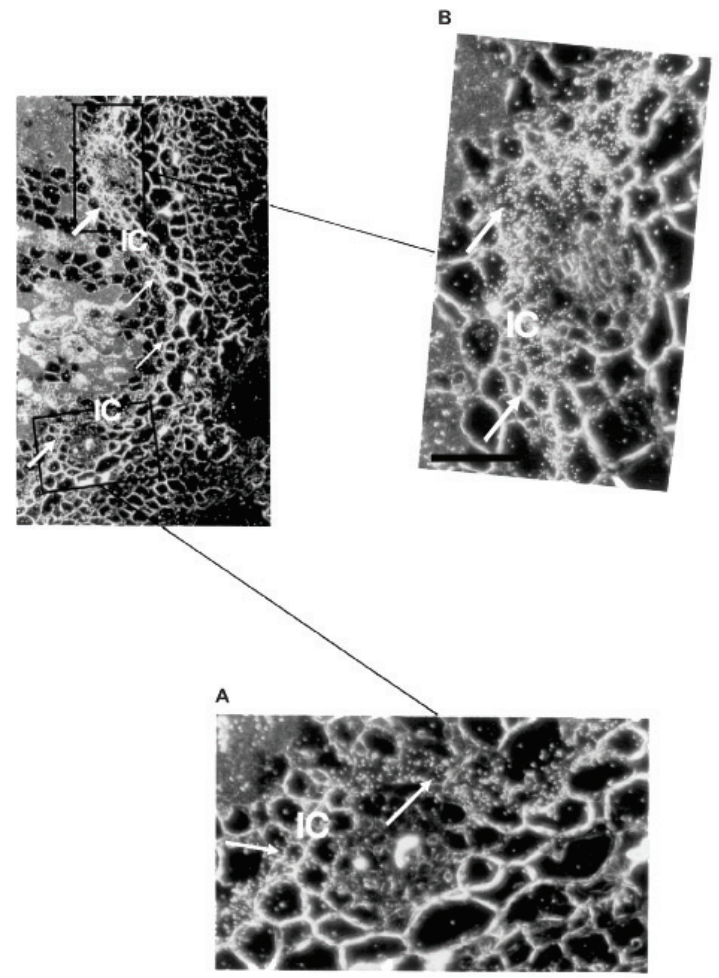

Figure 3. Differences in ISH signal with radioactive antisense- $P v C A$ probe in the nodule inner cortex (IC) in the vicinity (A and $\mathrm{B}$ ) and between the vascular traces (VT). White arrows show ISH signals. Dark bar corresponds to $50 \mu \mathrm{m}$.

tissues. Whatever the intensity of the signal in Figure 2, the $P v C A$ gene was expressed exclusively in the inner-cortex.

\subsection{Variations in nodular expression of Pvca}

Furthermore, the intensity of the ISH signal varied dramatically between nodules as shown by comparing A, B and $\mathrm{C}$ in Figure 2. Such variation was associated with nodules from different plants, though some variations were also found between nodules from one plant (data not shown). In addition, some variation in this signal could be found within one nodule. Thus, Figure 3 shows a lower ISH signal close to the vascular trace magnified in Figure 3A than that in Figure 3B, although both vascular traces were within one nodule. Moreover, the $P v C A$ expression was more intense in the vicinity than inbetween the vascular traces, as illustrated by the thickness of the white arrows in Figure 3.

These variations were not artefactual since they were distinct from the background ISH signal. The latter could be recognized by its random distribution in other nodule tissues and outside the section (see Figs. 2A and 2C, for example), or in the nodule cuts exposed to the sense probe (compare Figs. 2B and 2E, for example).

\subsection{Hybridization with a digoxygenin cold probe}

The use of a radioactive probe is limited by the requirement of a suitably-equipped laboratory and by the 1-month duration
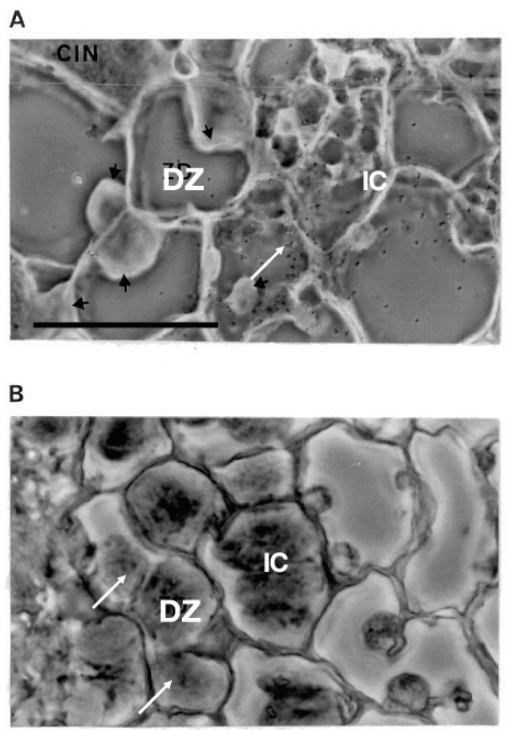

Figure 4. Differences in ISH signals with radioctive (A) or digoxygenine (B) $P v C A$ probes in nodule inner cortex. White arrows show ISH signals. Digoxygenine signal appears as a purple stain. Black arrows show amyloplasts. Dark bar corresponds to $50 \mu \mathrm{m}$.

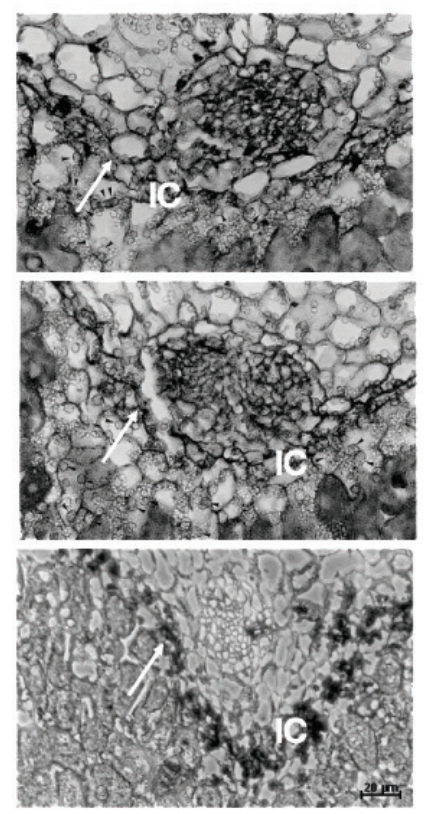

Figure 5. ISH signals with sense (A) and antisense (B) digoxygenine $P v C A$ probes, and with $(\mathrm{C})$ digoxygenine GUS probe in nodule inner cortex. White arrows show digoxygenine signals, as a brownishpurple stain. Black arrows show amyloplasts. Dark bar corresponds to $50 \mu \mathrm{m}$.

of the procedure. However, sections of resin-embedded nodules were hybridized with digoxygenin-labeled $P v C A$ probes. By contrast with the above results with a radioactive probe, major artefacts were found with the digoxygenin probe: (i) in the distributing zone (ZD), no signal was observed with antisense radioactive- $P v C A$ (Fig. $4 \mathrm{~A}$ ) although a signal was 
observed with antisense digoxygenin- $P v C A$ (Fig. 4B), and (ii) in the inner-cortex (IC), a similar signal was observed with the sense (Fig. 5A) and the antisense (Fig. 5B) digoxygenin$P v C A$ probe.

In order to test whether the above signals with digoxygeninPvCA were artefactual, hybridization was performed with a digoxygenin-GUS probe that could not hybridize with any $P$. vulgaris mRNA. The aspecificity of the digoxygenin signal is demonstrated in Figure 5C, where the signal of the digoxygenin GUS probe is localized similarly to that of the digoxygenin-PvCA in Figure 5B, i.e. close to amyloplasts.

\section{DISCUSSION}

In this work we show in situ hybridization results with a mRNA radioactive probe on sections of legume root-nodules previously embedded in a methacrylate resin. Thus methacrylate embedding is a reliable methodology for radioactive ISH with plant tissue, as previously reported with a cold probe [11] or with animal tissue [22].

Moreover, the precision of the results shown here with the radioactive antisense $P v C A$ probe makes it possible to consider using the ISH not only qualitatively, by localizing precisely the gene expression at the cellular level, but also quantitatively by counting the number of radioactive dots per cell, with image analysis software if needed.

In this work, we could localize the $P v C A$ expression precisely within the IC-cells of the common-bean nodule cortex. These IC-cells were previously characterized as exhibiting reversible contraction associated with a decrease in nodule permeability [20], and high content in tonoplast aquaporins [19]. Further work is required to verify whether the intensity of $P v C A$ and aquaporin expressions in IC-cells increases under deficiencies of phosphorus or oxygen, which increase nodule permeability $[16,17]$.

In addition, the high resolution of the ISH signals shown in this work with a radioactive RNA probe on methacrylateembedded biological material may lead to such rhizospheric applications as localizing and quantifying a microbial invasion of the endorhizosphere or the rhizoplan by using bacterial- or fungal-specific RNA probes.

Acknowledgments: This work was supported by contract ERBICT18CT960081 of the European Community.

\section{REFERENCES}

[1] Baskin T.I., Busby C.H., Fowke L.C., Sammut M., Gubler F., Improvements in immunostaining samples embedded in methacrylate: localization of microtubules and other antigens throughout developing organs in plants of diverse taxa, Planta 187 (1992) 405-413.

[2] Cox K.H., De Leon D.V., Angerer L.M., Angerer R.C., Detection of mRNAs in sea urchin embryos by in situ hybridization using asymmetric RNA Probes, Dev. Biol. 101 (1984) 485-502.

[3] David M., Daveran M.L., Batut J., Dedieu A., Domergue O., Ghai J., Hertig C., Boistard P., Kahn D., Cascade regulation of nif gene expression in Rhizobium meliloti, Cell 54 (1988) 671-683.
[4] De la Pena T.C., Frugier F., McKhann H.I., Bauer P., Brown S., Kondorosi A., Crespi M., A carbonic anhydrase gene is induced in the nodule primordium and its cell-specific expression is controlled by the presence of Rhizobium during development, Plant J. 11 (1997) 407-420.

[5] Drevon J.J., Frangne N., Fleurat-lessard P., Payre H., Ribet J., VadezV., Serraj R., Is nitrogenase-linked respiration regulated by osmocontractile cells in legume?, in: Elmerich C., Kondorosi A., Newton W.E. (Eds.), Biological Nitrogen Fixation for the 21st Century, Kluwer Academic Publishers, Dordrecht, The Netherlands, 1997, pp. 465-466.

[6] Drevon J.J., Deransart C., Fleurat-Lessard P., Jaillard B., Ndjiondjop M.N., Payre H., Ribet J., Roy G., Serraj R., Is the symbiotic fixation osmoregulated by reversible contraction of cells in the legume-nodule inner cortex?, in: Tikhonovitch I.A., Provorov N.A., Romanov V.I., Newton W.E. (Eds.), Nitrogen Fixation: Fundamentals and Applications, Kluwer Academic, Dordrecht, The Netherlands, 1995, p. 598.

[7] Drevon J.J., Kalia V.C., Heckmann M.-O., Pédelahore P., In situ open-flow assay of acetylene reduction activity by soybean rootnodules: influence of acetylene and oxygen, Plant Physiol. Biochem. 26 (1988) 73-78.

[8] Gherbi H., Duhoux E., Franche C., Katharina P., Nassar A., Berry A.M., Bogusz D., Cloning of a full-length symbiotic hemoglobin cDNA and in situ localization of the corresponding mRNA in Casuarina glauca root nodule, Physiol. Plant. 99 (1997) 608-616.

[9] Hunt S., Layzell D.B., Gas exchange of legume nodules and the regulation of nitrogenase activity, Annu. Rev. Plant Physiol. Plant Mol. Biol. 44 (1993) 483-511.

[10] James E.K., Sprent J.I., Minchin F.R., Brewin N.J., Intercellular location of glycoprotein in soybean nodules: effect of altered rhizosphere oxygen concentration, Plant Cell Environ. 14 (1991) 467-476.

[11] Kronenberger J., Desprez T., Höfte H., Caboche M., Traas J.G., A methacrylate embedding procedure developed for immunolocalization on plant is also compatible with in situ hybridisation, Cell Biol. Int. 17 (1993) 1013-1021.

[12] Luther P.W., Bloch R.J., Formaldehyde-amine fixatives for immunocytochemistry, J. Histochem. Cytochem. 37 (1989) 75-82.

[13] Majeau N., Arnoldo M.A., Coleman J.R., Modification of carbonic anhydrase activity by antisense and over-expression constructs in transgenic tobacco, Plant Mol. Biol. 25 (1994) 377-385.

[14] Parsons R., Day D.A., Mechanism of soybean nodule adaptation to different oxygen pressures, Plant Cell Environ. 13 (1990) 501512.

[16] Ribet J., Drevon J.J., Increase in permeability to oxygen and in oxygen uptake of soybean nodules under limiting phosphorus nutrition, Physiol. Plant. 94 (1995) 298-304.

[17] Ribet J., Drevon J.J., Phosphorus deficiency increases the acetylene induced decline of nitrogenase activity in soybean (Glycine $\max$ L. Merr.), J. Exp. Bot. 46 (1995) 1479-1486.

[18] Selker J.M.L., Three-dimensional organization of uninfected tissues in soybean root nodules and its relation to cell specialization in the central region, Protoplasma 147 (1988) 178-190.

[19] Serraj R., Frangne N., Maeshima M., Fleurat-Leussard P., Drevon J.J., A $\gamma$-TIP cross reacting protein is abundant in the cortex of soybean nitrogen-fixing nodules, Planta 206 (1998) 681-684.

[20] Serraj R., Fleurat-Lessart P., Jaillard B., Drevon J.J., Changes in soybean nodule cortical cells under short-term salt stress and altered oxygen concentration, Plant Cell Environ. 18 (1995) 455462.

[21] Vadez V., Rodier F., Payre H., Drevon J.J., Nodule permeability to oxygen and nitrogenase-linked respiration in bean genotypes varying in the tolerance of nitrogen fixation to P deficiency, Plant Physiol. Biochem. 34 (1996) 871-878.

[22] Warren K.C., Coyne K.J., Waite J.H., Cary S.C., Use of methacrylate de-embedding protocols for in situ hybridization on semithin plastic section with multiple detection strategies, J. Histochem. Cytochem. 46 (1998) 149-155. 